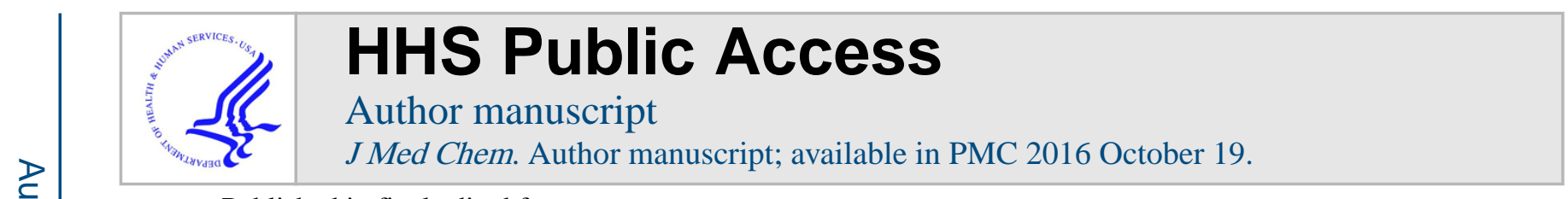

Published in final edited form as:

J Med Chem. 2015 December 24; 58(24): 9773-9778. doi:10.1021/acs.jmedchem.5b01285.

\title{
Discovery of Novel Potent and Selective Agonists at the Melanocortin-3 Receptor
}

\author{
Alfonso Carotenuto\#, Francesco Merlino\#, Minying Cai ${ }^{ \pm}$, Diego Brancaccio”, Ali Munaim \\ Yousif", Ettore Novellino", Victor J. Hruby ${ }^{ \pm}$, and Paolo Grieco\#,¥,* \\ \#Dipartimento di Farmacia, Università di Napoli Federico II, Via D. Montesano, 49, 80131, Naples, \\ Italy \\ ${ }^{¥}$ CIRPEB: Centro Interuniversitario di Ricerca sui Peptidi Bioattivi, University of Naples Federico \\ II, 80134, Naples, Italy \\ ¿Department of Chemistry and Biochemistry, University of Arizona, Tucson, Arizona 85721, \\ United States
}

\begin{abstract}
The melanocortin receptors 3 and 4 control energy homeostasis, food-intake behavior, and correlated pathophysiological conditions. The melanocortin-4 receptor (MC4R) has been broadly investigated. In contrast, the knowledge related to physiological roles of the melanocortin-3 receptor (MC3R) is lacking because of the limited number of known MC3R selective ligands. Here, we report the design, synthesis, biological activity, conformational analysis, and docking with receptors of two potent and selective agonists at the human MC3 receptor.
\end{abstract}

\section{Graphical Abstract}

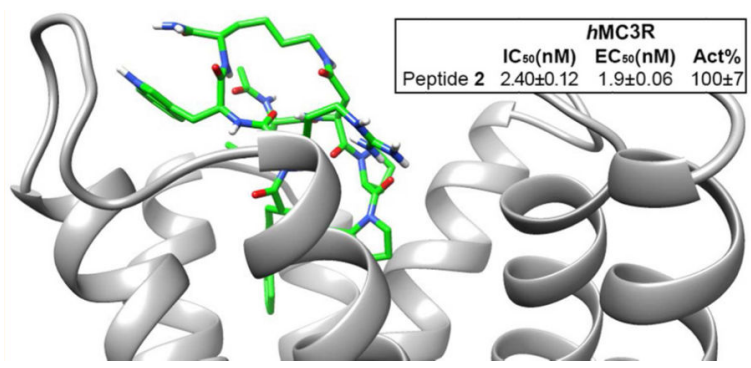

*Corresponding Author. Phone: +39-081678620. paolo.grieco@unina.it. ASSOCIATED CONTENT

Supporting Information

The Supporting Information is available free of charge on the ACS Publications website at DOI: 10.1021/acs.jmedchem.5b01285.

Analytical data of the synthesized peptides, NMR data of the analyzed peptides, statistics of homology building and
docking procedures (PDF)
Molecular formula strings (CSV)

The authors declare no competing financial interest. 


\section{INTRODUCTION}

The family of melanocortin receptors (MCRs) together with their endogenous ligands is engaged in the modulation of numerous pathophysiological pathways including feeding behavior and energy homeostasis, skin pigmentation, sexual function, as well as several other critical biological activities. ${ }^{1}$ The endogenous melanocortin agonists, also known as the melanocortin peptides, consist of $\alpha-, \beta$-, and $\gamma$-melanocyte-stimulating hormones (MSH) and adrenocorticotropic hormone (ACTH). ${ }^{2}$ In humans, five different receptor subtypes, referred to as human melanocortin receptors $1-5(h \mathrm{MC} 1-5 \mathrm{R})$, have been discovered, to date. All of them belong to the rhodopsin family of seven-transmembrane-helix $G$ protein-coupled receptors (GPCRs) and convey their effects in the cytosol by activating cAMP-dependent pathways, generating a cascade of specific intracellular events. ${ }^{3}$ All melanocortin peptides are agonists toward $h \mathrm{MCRs}$, except for the $h \mathrm{MC} 2 \mathrm{R}$, which is exclusively recognized by ACTH that acts as a full agonist as well. ${ }^{4}$ In contrast, the endogenous $h$ MCRs antagonists comprise the agouti signaling protein (hASIP, also known as the "agouti protein"), which mainly binds to the $h \mathrm{MC} 1 \mathrm{R}$ and $h \mathrm{MC} 4 \mathrm{R}$ but displaying lower affinity toward the $h \mathrm{MC} 3 \mathrm{R}$, and the agouti-related protein ( $h$ AGRP) that acts as selective ligand at the $h \mathrm{MC} 3,4 \mathrm{R}$ subtypes. ${ }^{5}$ Intense efforts are addressed to the development of selective molecules active at the melanocortin receptors. In particular, shedding light on the role of melanocortin receptor subtypes expressed in the brain, i.e., $h \mathrm{MC} 3 \mathrm{R}, h \mathrm{MC} 4 \mathrm{R}$, and $h \mathrm{MC} 5 \mathrm{R}$, is intriguing considering the discovery that $\mathrm{MC} 3 \mathrm{R}$ and $\mathrm{MC} 4 \mathrm{R}$ are engaged in the control of food-intake behavior. ${ }^{5,6}$ Extensive structure-activity relationship studies (SARs) on melanocortins, particularly upon a-MSH, have turned out to be useful for the development of small cyclic peptides such as MT-II, Ac-Nle ${ }^{4}$-c[Asp ${ }^{5}-\mathrm{His}^{6}{ }^{6} \mathrm{DPhe}^{7}-\mathrm{Arg}^{8}$-Trp ${ }^{9}-\mathrm{Lys}^{10}{ }^{10}-\mathrm{NH}_{2},{ }^{7}$ a potent but not selective agonist at the $h \mathrm{MC} 1,3,4,5 \mathrm{R}$, and SHU-9119, Ac-Nle ${ }^{4}-\mathrm{c}\left[\mathrm{Asp}^{5}\right.$-His $^{6}-\mathrm{D}\left(2^{\prime}\right) \mathrm{Nal}^{7}-$ $\mathrm{Arg}^{8}{ }^{-} \mathrm{Trp}^{9}$-Lys $\left.{ }^{10}\right]-\mathrm{NH}_{2}$, a nonselective antagonist with high affinity at the $h \mathrm{MC} 3,4 \mathrm{R}$ and an agonist at the $h \mathrm{MC} 1,5 \mathrm{R} .{ }^{8}$ Further structure-activity studies have revealed that exchanging the His residue in position 6 in both sequences of MT-II ${ }^{9}$ and SHU- $9119^{10}$ with Pro residue is well tolerated, generating cyclic peptides with similar/improved activity profiles compared to the corresponding parent peptide.

Herein, we report the synthesis, the biological activity at $h \mathrm{MC} 1$ and $h \mathrm{MC} 3-5 \mathrm{R}$, and the conformational analysis of a few analogues in which a $\mathrm{Xaa}^{6}-\mathrm{Pro}^{7}$ dipeptide replaced the His $^{6}$ residue of MT-II or SHU9119 (Table 1), some of which resulted in potent and selective agonists at the human $\mathrm{MC} 3$ receptor.

\section{RESULTS AND DISCUSSION}

\section{Design of Novel Ligands}

Starting from Pro ${ }^{6}$ analogue of both MT-II and SHU9119, novel derivatives were designed by the insertion of an additional residue before Pro $^{6}$; in fact, the increase of ring size from 23- to 26-mer did not significantly affect the ligand binding at human melanocortin receptors in $\mathrm{His}^{6}$ as well as in $\mathrm{Pro}^{6}$ derivatives. ${ }^{11,12}$ It is well-known that $\mathrm{L}$-proline residue in proteins and peptides has remarkable effects on their secondary structures. The presence of prolines induces unique properties to proteins due to their conformational restriction, lack of a hydrogen bond donor on the amide, and their propensity to form a cis amide bond, due 
mainly to the differential sterics of a secondary vs tertiary amide bond. In this context, residues preceding proline in Xaa-Pro influence the percentage of the cis Xaa-Pro bonds in peptides and proteins. ${ }^{13}$ In particular, Pro and Trp residues in the Xaa position gave the lowest (6\%) and highest (37.7\%) fraction of cis isomer, respectively. Hence we chose those two amino acids obtaining the analogues 1-4 (Table 1).

\section{Peptide Synthesis}

Peptides 1-4 were manually synthesized by adopting a solid-phase strategy and a Fmoc/ $t \mathrm{Bu}$ chemistry for orthogonal protection of functional groups. The physicochemical properties and purity of these peptides are reported in Table S1 and Figures S1-S4 (Supporting Information (SI)).

\section{Biological Data}

Table 1 summarizes the binding affinities of the novel analogues along with intracellular cAMP accumulation in cloned human MC1R, MC3R, MC4R, and MC5R. For comparison, MT-II data are also reported. The Pro ${ }^{6}-\mathrm{Pro}^{7}-\mathrm{DPhe}^{8}$ analogue (1) shows no appreciable binding at the $h \mathrm{MC} 1 \mathrm{R}$ and $h \mathrm{MC} 5 \mathrm{R}$ and low binding affinity at the $h \mathrm{MC} 3 \mathrm{R}$ and $h \mathrm{MC} 4 \mathrm{R}$. Accordingly, low potency ( $h \mathrm{MC} 1 \mathrm{R})$ or undetectable activity ( $h \mathrm{MC} 3-5 \mathrm{Rs})$ is observed in functional assays. In contrast, the $\operatorname{Pro}^{6}-\mathrm{Pro}^{7}-\mathrm{DNal}\left(2^{\prime}\right)^{8}$ analogue (2) shows strong binding affinity and selectivity for the $h \mathrm{MC} 3 \mathrm{R}\left(K_{\mathrm{i}}=2.4 \mathrm{nM}\right)$ vs the $h \mathrm{MC} 1 \mathrm{R}$ and $h \mathrm{MC} 4 \mathrm{R}-h \mathrm{MC} 5 \mathrm{Rs}$ by $2-3$ orders of magnitude. It also displays potent activity at the $h \mathrm{MC} 3 \mathrm{R}\left(\mathrm{EC}_{50}=1.9 \mathrm{nM}\right)$ behaving as a full agonist and is about 10-fold more selective at this receptor compared with the $h \mathrm{MC} 5 \mathrm{R}$, whereas it does not increase cAMP through the $h \mathrm{MC} 4 \mathrm{R}$. The $\operatorname{Trp}^{6}-\mathrm{Pro}^{7}-\mathrm{DPhe}{ }^{8}$ analogue (3) shows weak binding at the $h \mathrm{MC} 3 \mathrm{R}$ and no affinity for the $h \mathrm{MC} 1 \mathrm{R}, h \mathrm{MC} 4 \mathrm{R}-$ $h$ MC5Rs (Table 1). It also exhibits no stimulation of cAMP accumulation at the $h \mathrm{MC} 3 \mathrm{R}$ and weak and moderate activation of the $h \mathrm{MC} 1 \mathrm{R}, h \mathrm{MC} 4 \mathrm{R}-h \mathrm{MC} 5 \mathrm{R} s$. To note, the $\operatorname{Trp}^{6}-\mathrm{Pro}^{7}-$ $\operatorname{DNal}\left(2^{\prime}\right)^{8}$ analogue (4) shows strong binding affinity and selectivity for the $h \mathrm{MC} 3 \mathrm{R}\left(K_{\mathrm{i}}=\right.$ $11.0 \mathrm{nM}$ ) vs the $h \mathrm{MC} 1 \mathrm{R}, h \mathrm{MC} 4 \mathrm{R}-h \mathrm{MC} 5 \mathrm{Rs}$ by at least 2 orders of magnitude. It also shows moderate activity at the $h \mathrm{MC} 3 \mathrm{R}\left(\mathrm{EC}_{50}=42 \mathrm{nM}\right)$ with a partial agonist behavior and is about 500 -fold more selective at this receptor compared with the $h \mathrm{MC} 4 \mathrm{R}$ while it also stimulates cAMP accumulation at $h \mathrm{MC} 5 \mathrm{R}\left(\mathrm{EC}_{50}=20 \mathrm{nM}\right)$. Hence, peptides $\mathbf{2}$ and $\mathbf{4}$ are potent and selective (at least considering $h \mathrm{MC} 4 \mathrm{R}$ ) agonists at the $h \mathrm{MC} 3 \mathrm{R}$. It is well-known that MC3R and MC4R agonist ligands reduce food intake. ${ }^{14} \mathrm{By}$ the way, the use of selective agonists toward the $h \mathrm{MC} 4 \mathrm{R}$ promotes hypertension because of a MC4R-mediated process that has not been completely figured out yet. ${ }^{15}$ Therefore, acting selectively at the $h \mathrm{MC} 3 \mathrm{R}$ may be a more interesting target suitable for energy homeostasis therapies. Although the compounds 2 and $\mathbf{4}$ show an agonist activity at $h \mathrm{MC} 5 \mathrm{R}$, the low profile in binding affinity at this receptor limits their capability to be used as useful ligands at this receptor. The development of peptides $\mathbf{2}$ and $\mathbf{4}$ can thus prove to be very useful in the perspective of existence of very few selective and "clean" MC3R ligands that can be used to fully elucidate the receptor function.

\section{NMR Analysis}

NMR spectra of active compounds $\mathbf{2}$ and $\mathbf{4}$ were collected in a $200 \mathrm{mM}$ aqueous solution of DPC. For comparison purpose also inactive peptide $\mathbf{1}$ was studied by NMR. DPC micelle 
solutions were employed because they mimic membrane environments and are diffusely used for structural studies of peptide neurotransmitters and hormones. ${ }^{16}$ As a consequence of the conformational restrictions imposed by the cis/trans interconversion of the Pro amide bond, peptides 1-2 showed two slowly interchangeable conformational states (indicated as I and II) with populations of about 50 and $40 \%$ for state I in peptides $\mathbf{1}$ and $\mathbf{2}$, respectively. For both states, an almost complete assignment could be achieved for all proton resonances according to the Wüthrich ${ }^{17}$ strategy via the usual systematic application of DQF-COSY, ${ }^{18}$ TOCSY, ${ }^{19}$ and NOESY ${ }^{20}$ experiments with the support of the XEASY software package (Supporting Information, Tables S2-S5, SI). Sequential NOE connectivities of the a-protons of $\mathrm{Asp}^{5}$ and $\mathrm{Pro}^{6}$ with the $\delta$-protons of $\mathrm{Pro}^{6}$ and $\mathrm{Pro}^{7}$, respectively, provide evidence that in state I both Xaa-Pro amide bonds have the trans configuration (I: trans-trans). Conversely, NOE connectivity between a-proton of residues Asp ${ }^{5}$ and the $\delta$-protons of Pro $^{6}$ and between a-protons of residues $\mathrm{Pro}^{6}$ and $\mathrm{Pro}^{7}$, indicates the trans-cis configurations of the consecutive Asp ${ }^{5}-\mathrm{Pro}^{6}$ and Pro $^{6}-\mathrm{Pro}^{7}$ amide bonds in state II (II: trans-cis). Considering peptide 4, only one state could be observed which could be determined as the trans-cis state (SI, Table S6). Thus, according to the design strategy, a Trp residue preceding the Pro ${ }^{7}$ residue stabilized a cis amide bond. A single configuration state of $\mathbf{4}$ is observed also in water solution (data not shown) and supports the idea that the trans-cis state is the one interacting with the receptor. Chemical shift values of protons belonging to state I of peptides 1-2 (SI, Tables S2 and S4) proved to be very similar to those observed in random coil peptides $(\Delta \delta<0.1 \mathrm{ppm}),{ }^{21}$ while proton resonances of state II of peptides $\mathbf{1 - 2}$ and of the unique signal system of peptide 4 (SI, Tables S3, S5, and S6) were significantly different ( $|\Delta \delta|>0.1 \mathrm{ppm}$ for all the $\mathrm{H}_{\mathrm{a}}$-resonances), indicating a marked conformational stability of this state. The NOESY spectra of peptides 1, 2, and $\mathbf{4}$ are shown in SI, Figures S5-S7, respectively. Considering the state I of peptides 1-2, only intra-residue or sequential NOEs could be unambiguously assigned indicating random conformations associated with this isomer as indicated also by the chemical shift analysis. In contrast, several NMR parameters indicate that the cis $\mathrm{Xaa}^{6}-\mathrm{Pro}^{7}$ state of all the peptides is highly structured. In fact, ${ }^{3} J_{\mathrm{HN}-\mathrm{Ha}}$ coupling constants (SI, Tables S3, S5 and S6), $\mathrm{H}_{\mathrm{a}}$ CSI values ${ }^{21}$ (SI, Figure S8), and some NOE signals (SI, Table S7) point to a $\beta$-hairpin structure centered on the Xaa ${ }^{6}-P^{2}{ }^{7} \beta$-turn. Diagnostic medium range NOE interactions $d_{\mathrm{aN}}(i, i+2) 6-8$ observed in the NOESY spectra are typical of a $\beta$-turn structure.

This result was enforced by the registration of low value of the temperature coefficient for $\mathrm{NH}$ resonance of residue $8(-\Delta \delta / \Delta T<3.0 \mathrm{ppb} / \mathrm{K})$. Large values of ${ }^{3} J_{\mathrm{HN}-\mathrm{Ha}}$ coupling constants $\left({ }^{3} \mathrm{JHN}_{\mathrm{HNa}}>8 \mathrm{~Hz}\right)$ of residues 5 and $8-9$ and downfield shift of a-proton resonances of residues 4-5 and 8-10 flanking the $\beta$-turn together with long-range NOE's between $\mathrm{H}_{\mathrm{a}}$ of $\mathrm{Nle}^{4}$ and $\mathrm{H}_{\mathrm{a}}$ of $\operatorname{Trp}^{10}, \mathrm{H}_{\mathrm{a}}$ of $\mathrm{Nle}^{4}$, and $\mathrm{H}_{\mathrm{N}}$ of Lys ${ }^{11}$ point to a short antiparallel $\beta$-sheet structure along those residues. Different NOEs connected the $\mathrm{Nle}^{4}$ side chain with both $\mathrm{DPhe}^{8} / \mathrm{DNal}\left(2^{\prime}\right)^{8}$ and $\operatorname{Trp}^{10}$ aromatic moieties pointing to spatial closeness of these side chains. NMR-derived constraints registered for the analyzed peptides (SI, Table S7) were used as the input data for a simulated annealing structure calculation. Only state II was considered for structure calculation of peptides $\mathbf{1}$ and $\mathbf{2}$. For each peptide, 10 calculated structures satisfying the NMR-derived constraints (violations smaller than $0.20 \AA$ ) were chosen (Figure 1a-c). All peptides show a distorted type VIa1 $\beta$-turn structure flanked by a 
short $\beta$-sheet encompassing residue 4-5 and 9-10 (backbone rmsd values are $0.41,0.34$, and $0.35 \AA$, for peptides $\mathbf{1}, \mathbf{2}$, and $\mathbf{4}$, respectively). Considering the side chains orientation, $\operatorname{DNal}\left(2^{\prime}\right)^{8}$ showed a large preference for $\mathrm{g}^{+}$rotamer of $\chi^{1}$ angle, thus closely interacting with Pro ${ }^{6}$ in peptide 2 (Figure 1b) or $\operatorname{Trp}^{6}$ in peptide 4 (Figure 1c). Moreover, the indole moiety of $\operatorname{Trp}^{6}$ of peptide 4 strongly interacts with the $\mathrm{Pro}^{7}$ side chain. These interactions give rise to the observed stability of Xaa-Pro ${ }^{7}$ cis amide bond. A consequence of such close proximity is the ring current effect on a-proton of residue $6\left(\Delta \delta \mathrm{H}_{\mathrm{a}}=-0.61\right.$, and $-0.71 \mathrm{ppm}$ for $\mathbf{2}$, and $\mathbf{4}$, respectively, compared to random coil peptides). ${ }^{21}$ Furthermore, in peptide $\mathbf{4}$, a dramatic upfield shift is observed for $\alpha$ - and $\beta$-protons of $\operatorname{Pro}^{7}$, shielded by $\operatorname{Trp}^{6}$ indole moiety $\left(\Delta \delta \sim-2 \mathrm{ppm}\right.$ ), and for some protons of $\operatorname{Trp}^{6}$ indole itself $\left(\Delta \delta \mathrm{H}_{\varepsilon 3}=-1.39 \mathrm{ppm}, \mathrm{H}_{\zeta 3}\right.$ $=-0.67 \mathrm{ppm}$ ), shielded by DNal $\left(2^{\prime}\right)^{8}$ naphthyl moiety. In contrast, the DPhe ${ }^{8}$ side chain orientation of peptide 1 is less defined. In most cases (9/10), $\chi 1$ angle has a trans orientation placing the DPhe ${ }^{8}$ phenyl far from Pro $^{6}$ (Figure 1a).

The peptides surface is amphipathic. As shown in Figure 1, considering the pseudoplane determined by the backbone atoms, the hydrophobic residues $\mathrm{Nle}^{4}, \mathrm{Pro}^{6} / \mathrm{Trp}^{6}, \mathrm{DPhe}^{8} /$ $\operatorname{DNal}\left(2^{\prime}\right)^{8}$, and $\operatorname{Trp}^{10}$ lie on one side (right) and the positively charged residue Arg ${ }^{9}$ lies on the other side. Such an amphipathic arrangement was already observed for the NMR structure of parent peptides MT-II and SHU-9119. ${ }^{16}$ For each peptide, ensembles of 10 NMR structures were submitted to the PDB (PDB ID: 2N7N, 1; 2N7O, 2; 2N7T, 4).

\section{$h M C 3 R$ and $h M C 4 R$ Models and Docking}

Three-dimensional models of $h \mathrm{MC} 3 \mathrm{R}$ and $h \mathrm{MC} 4 \mathrm{R}$ were generated based on the structure of other GPCR's, using the I-TASSER server. ${ }^{22}$ Five models of both receptors were generated. I-TASSER output also contained top ranks of templates used for the structure prediction. The top template used is the high-resolution crystal structure of a human A2A adenosine receptor (PDB ID: 3EML). ${ }^{23}$ Statistical analyses on the obtained models are reported in SI, Table S8. Interestingly, the selected models maintain the molecular signatures which feature class A GPCRs, ${ }^{24}$ in fact, in both models are preserved 24 out of the 24 inter-TM contacts of the consensus network found in the GPCR structures. Peptide 2 NMR lowest energy structure was docked with both $h \mathrm{MC} 3 \mathrm{R}$ and $h \mathrm{MC} 4 \mathrm{R}$ models. Docking procedures using the program AUTODOCK ${ }^{25}$ clustered 100 poses in three clusters (80/100 poses in the first cluster) for the complexes $2 / h \mathrm{MC} 3 \mathrm{R}$ and 100 poses in 11 clusters for $2 / h \mathrm{MC} 4 \mathrm{R}(12 / 100$ poses in the first cluster). Statistics and energy terms are reported in SI, Table S9.

Clearly, the high number of clusters and their high energy (SI, Table S9) indicate that docking did not provide a suitable $2 / h \mathrm{MC} 4 \mathrm{R}$ complex in accordance with the binding data. In contrast, a high populated low energy cluster was obtained for $2 / h \mathrm{MC} 3 \mathrm{R}$ complex, and the best scored pose is shown in Figure 2. The predicted binding site is placed among TM3/ TM7, EL1, and EL3 (Figure 2a). Main interactions between the peptide and $h$ MC3R are shown in Figure 2b. As shown, most of the peptide interactions are established with side chains of residues belonging to EL1 and EL3, whose sequences are less conserved between $h \mathrm{MC} 3 \mathrm{R}$ and $h \mathrm{MC} 4 \mathrm{R}$ compared to the TM's regions, again in accordance with the observed selectivity. Moreover, many interactions are observed between the naphthyl group of $\mathrm{DNal}\left(2^{\prime}\right)^{8}$ and the receptor. Hence, its replacement with a smaller phenyl group in peptide $\mathbf{1}$ 
as well as the different orientation of the same phenyl compared to the naphthyl can tentatively explain the observed inactivity of the DPhe ${ }^{8}$ containing peptide $\mathbf{1}$ (and $\mathbf{3}$ ).

\section{CONCLUSION}

In conclusion, we have successfully developed two novel selective $h \mathrm{MC} 3 \mathrm{R}$ agonists. These compounds will represent suitable pharmacological tools for elucidating the receptor functions and can be considered as lead compounds for the design of novel $h \mathrm{MC} 3 \mathrm{R}$ ligands.

\section{EXPERIMENTAL SECTION}

\section{Materials}

$\mathrm{N}_{\mathrm{a}}$-Fmoc-protected amino acids, $\mathrm{HBTU}$, and $\mathrm{HOBt}$ were purchased from Inbios (Naples, Italy). Rink amide resin was purchased from GL Biochem (Shanghai, China).

99.9\% ${ }^{2} \mathrm{H}_{2} \mathrm{O}$ were obtained from Aldrich (Milwaukee, USA), 98\% DPC- $d_{38}$ was obtained from Cambridge Isotope Laboratories, Inc. (Andover, USA), and [(2,2,3,3-tetradeuterio-3(trimethylsilanyl)]-propionic acid (TSP) was obtained from MSD Isotopes (Montreal, Canada).

\section{Synthesis}

Synthesis of peptides 1-4 was performed by standard solid-phase peptide synthesis (SPPS) by using a Fmoc/ $t \mathrm{Bu}$ orthogonal strategy on a Rink amide resin as solid support. ${ }^{26}$ Further couplings were carried out with standard in situ activating reagents, such as uronium salts (HBTU), in the presence of a tertiary base (DIPEA), to generate HOBt esters. Lactam cyclization was performed on the resin after removal of the allyl-derived protecting groups employing the procedure described by Thieriet et al. ${ }^{27,28}$ All compounds were purified by RP-HPLC and verified by analytical UHPLC (SI). The physicochemical properties and purity (>95\%) of these peptides were assessed by LC-MS and HRMS (SI, Table S1, Figures S1-S4).

\section{Binding Assays}

Competition binding experiments were performed on whole cells. Stably transfected HEK293 cell lines having the individual $h \mathrm{MCRs}^{29,30}$ were seeded on 96-well plate $48 \mathrm{~h}$ before the assay and grown to 100000 cells/well. For the assay, the medium was removed and cells were washed twice with a freshly prepared binding buffer containing $100 \%$ minimum essential medium with Earle's salt (MEM, GIBCO), 25 mM HEPES (pH 7.4), $0.2 \%$ bovine serum albumin, $1 \mathrm{mM} \mathrm{1,10-phenanthrolone,} 0.5 \mathrm{mg} / \mathrm{L}$ leupeptin, and $200 \mathrm{mg} / \mathrm{L}$ bacitracin. Cells were then incubated with different concentrations of unlabeled peptides and ${ }^{125}$ I-labeled $\left[\mathrm{Nle}^{4}, \mathrm{DPhe}{ }^{7}\right]$-a-MSH (PerkinElmer Life Science, $100000 \mathrm{cpm} /$ well, $0.1386 \mathrm{nM}$ ) for $40 \mathrm{~min}$ at $37{ }^{\circ} \mathrm{C}$. The medium was subsequently removed, and each well was washed twice with the binding buffer. The cells were lysed by the addition of $250 \mu \mathrm{L}$ of 0.1 $\mathrm{mM} \mathrm{NaOH}$ and $250 \mu \mathrm{L}$ of $1 \%$ Triton X-100. The lysed cells were transferred to the $12 \mathrm{~mm} \times$ $75 \mathrm{~mm}$ glass tubes, and the radioactivity was measured using a Wallac 1470 WIZARD $\gamma$ 
counter. Data were analyzed using Graphpad Prism 3.1 (Graphpad Software, San Diego, CA).

\section{Adenylate Cyclase Assays}

HEK 293 cells stably transfected with individual human melanocortin receptors ${ }^{29,30}$ were grown to confluence in MEM medium (GIBCO) containing 10\% fetal bovine serum, 100 units $/ \mathrm{mL}$ penicillin and streptomycin, and $1 \mathrm{mM}$ sodium pyruvate. The cells were seeded on 96-well plates $48 \mathrm{~h}$ before assay and grown to 100000 cells/well. For the assay, the medium was removed and cells were rinsed with $1 \mathrm{~mL}$ of MEM buffer (GIBCO) or with Earle's Balanced Salt Solution (EBSS, GIBCO). An aliquot $(0.4 \mathrm{~mL})$ of the Earle's Balanced Salt Solution was placed in each well along with isobutylmethylxanthine (IBMX, $5 \mu \mathrm{L}, 0.5 \mathrm{mM}$ ) for $1 \mathrm{~min}$ at $37^{\circ} \mathrm{C}$. Next, various concentrations of melanotropins $(0.1 \mathrm{~mL})$ were added and the cells were incubated for $3 \mathrm{~min}$ at $37^{\circ} \mathrm{C}$. The reaction was stopped by aspirating the buffer and adding ice-cold Tris/EDTA buffer to each well $(0.15 \mathrm{~mL})$. After the cells were dislodged with the help of trypsin, the cells were transferred to polypropylene microcentrifuge tubes, capped, and placed in a boiling water bath for $15 \mathrm{~min}$. The cell lysate was then centrifuged for $2 \mathrm{~min}(6500 \mathrm{rpm})$, and $50 \mu \mathrm{L}$ of the supernatant was aliquoted into a clean Eppendorf tube. The total cAMP content was measured by competitive binding assay according to the assay kit instructions (TRK 432, Amersham Corp., Arlington Heights, IL

\section{Data Analysis}

$\mathrm{IC}_{50}$ and $\mathrm{EC}_{50}$ values represent the mean of duplicate experiments performed in triplicate.

$\mathrm{IC}_{50}$ and $\mathrm{EC}_{50}$ estimates and their associated standard errors were determined by fitting the data using a nonlinear least-squares analysis, with the help of Graphpad Prism 3.1

(Graphpad Software, San Diego, CA).

\section{NMR Spectroscopy}

The samples for NMR spectroscopy were prepared by dissolving the appropriate amount of peptides in $0.27 \mathrm{~mL}$ of ${ }^{1} \mathrm{H}_{2} \mathrm{O}$ (pH 5.5) AND $0.03 \mathrm{~mL}$ of ${ }^{2} \mathrm{H}_{2} \mathrm{O}$ to obtain a concentration 1-2 $\mathrm{mM}$ of peptide. For the sample in micelle solution, DPC- $d_{38}$ was also added to a concentration of $200 \mathrm{mM}$. NMR spectra were recorded on a Varian INOVA $700 \mathrm{MHz}$ spectrometer equipped with a $z$-gradient $5 \mathrm{~mm}$ triple-resonance probe head. $1 \mathrm{D}$ and $2 \mathrm{D}$ NMR spectra were recorded and processed as described in the SI.

\section{Structural Determinations}

The NOE-based distance restraints, obtained in DPC solution, were obtained from NOESY spectra collected with a mixing time of $100 \mathrm{~ms}$. The NOE cross peaks were integrated with the XEASY program and were converted into upper distance bounds using the CALIBA program incorporated into the program package DYANA. ${ }^{31}$ Only NOE derived constraints (SI, Table S7) were considered in the annealing procedures. An ensemble of 100 structures was generated with the simulated annealing calculations followed by successive steps of restrained and unrestrained energy minimization using the Discover algorithm (Accelrys, San Diego, CA) as previously described. ${ }^{16}$ From the produced 100 conformation, 10 structures were chosen whose interproton distances best fitted NOE derived distances. 


\section{Receptor Models and Docking}

Three-dimensional structure predictions of $h \mathrm{MC} 3 \mathrm{R}$ and $h \mathrm{MC} 4 \mathrm{R}$ were generated by ITASSER server for protein structure and function prediction, which is based on a threading alignment algorithm. ${ }^{22}$ The best scored model for each receptor was used for docking studies (SI, Table S8). The initial poses for the $h \mathrm{MCR}$-peptide $\mathbf{2}$ complex are generated by docking the lowest energy conformers of peptide 2 obtained by NMR to the $h \mathrm{MC} 3 \mathrm{R}$ or $h \mathrm{MC} 4 \mathrm{R}$ model using the program AUTODOCK 4.0. ${ }^{25}$ Only the side chain of $\mathrm{Arg}^{9}$ of peptide 2 was considered flexible in the docking procedure. Statistics are reported in SI, Table S9. Refinement of lowest energy pose of $h \mathrm{MC} 3 \mathrm{R}-\mathbf{2}$ complex was achieved by in vacuo energy minimization with the Discover algorithm using the steepest descent and conjugate gradient methods until a RMSD of $0.05 \mathrm{kcal} / \mathrm{mol}$ per $\AA$ was reached. The backbone atoms of the TM and IL domains of the $h \mathrm{MC} 3 \mathrm{R}$ were held in their position; the ligand and EL's were free to relax.

\section{Supplementary Material}

Refer to Web version on PubMed Central for supplementary material.

\section{Acknowledgments}

This work was supported in part by a grant from the US Public Health Service, NIH IRO12M108040 and Italian grant, MIUR, PRIN2011, 2010MCLBCZ_002.

\section{ABBREVIATIONS USED}

$\begin{array}{ll}\text { hMCR } & \text { human melanocortin receptor } \\ \text { CAMP } & \text { cyclic adenosine monophosphate } \\ \text { GPCR } & \text { G-protein-coupled receptor } \\ \text { MSH } & \text { melanocyte stimulating hormones } \\ \text { ACTH } & \text { adrenocorticotropic hormone } \\ \text { POMC } & \text { proopiomelanocortin } \\ \text { AGRP } & \text { agouti-related protein } \\ \text { ASIP } & \text { agouti signaling protein } \\ \text { DPC } & \text { dodecyl phosphocholine } \\ \text { NMR } & \text { nuclear magnetic resonance } \\ \text { DQF-COSY double quantum filtered correlated spectroscopy } \\ \text { TOCSY } & \text { total correlated spectroscopy } \\ \text { NOESY } & \text { nuclear Overhauser enhancement spectroscopy } \\ \text { NOE } & \text { nuclear Overhauser effect }\end{array}$




$\begin{array}{ll}\text { TSP } & \text { 3-(trimethylsilanyl)propionic acid } \\ \text { IL } & \text { intracellular loop } \\ \text { EL } & \text { extracellular loop } \\ \text { TM } & \text { trans-membrane domain } \\ \text { Nal(2') } & \left(2^{\prime}\right) \text {-naphthylalanine } \\ \text { Fmoc } & \text { 9-fluorenylmethoxycarbonyl } \\ \text { HBTU } & N, N, N^{\prime}, N^{\prime} \text {-tetramethyl- } O \text { - }(1 H \text {-benzotriazol-1-yl)uroniumhexa- } \\ & \text { fluorophosphate } \\ \text { HOBt } & \text { 1-hydroxybenzotriazole } \\ \text { DIPEA } & N, N \text {-diisopropylethylamine } \\ \text { All } & \text { allyl } \\ \text { Aloc } & \text { allyloxycarbonyl }\end{array}$

MALDI-TOFatrix-assisted laser desorption ionization/time-of-flight mass spectrometry

RP-HPLC reversed-phase high performance liquid chromatography

SPPS solid-phase peptide synthesis

\section{REFERENCES}

1. Cone RD. Studies on the Physiological Functions of the Melanocortin System. Endocr. Rev. 2006; 27(7):736-749. [PubMed: 17077189]

2. Mountjoy, KG. Cloning of the Melanocortin Receptors. In: Cone, RD., editor. Melanocortin Receptors. Totowa, NJ: Humana Press; 2000. p. 209-235.

3. Pritchard LE, Turnbull AV, White A. Pro-Opiomelanocortin Processing in the Hypothalamus: Impact on Melanocortin Signalling and Obesity. J. Endocrinol. 2002; 172(3):411-421. [PubMed: 11874690]

4. Schiöth HB, Chhajlani V, Muceniece R, Klusa V, Wikberg JE. Major Pharmacological Distinction of the ACTH Receptor from Other Melanocortin Receptors. Life Sci. 1996; 59(10):797-801. [PubMed: 8761313]

5. McNulty JC, Jackson PJ, Thompson DA, Chai B, Gantz I, Barsh GS, Dawson PE, Millhauser GL. Structures of the Agouti Signaling Protein. J. Mol. Biol. 2005; 346(4):1059-1070. [PubMed: 15701517]

6. Fan W, Boston BA, Kesterson RA, Hruby VJ, Cone RD. Role of Melanocortinergic Neurons in Feeding and the Agouti Obesity Syndrome. Nature. 1997; 385(6612):165-168. [PubMed: 8990120]

7. Al-Obeidi F, Castrucci AM, Hadley ME, Hruby VJ. Potent and Prolonged Acting Cyclic Lactam Analogues of Alpha-Melanotropin: Design Based on Molecular Dynamics. J. Med. Chem. 1989; 32(12):2555-2561. [PubMed: 2555512]

8. Hrubuy VJ, Lu D, Sharma SD, De L, Castrucci A, Kesterson RA, Al-Obeidi FA, Hadley ME, Cone RD. Cyclic Lactam a-Melanotropin Analogues of Ac-Nle4-cyclo[Asp5,D-Phe7,-Lys10] aMelanocyte-Stimulating Hormone-(4-10)-NH2 with Bulky Aromatic Amino Acids at Position 7 Show High Antagonist Potency and Selectivity at Specific Melanocortin Receptors. J. Med. Chem. 1995; 38(18):3454-3461. [PubMed: 7658432] 
9. Bednarek MA, Macneil T, Kalyani RN, Tang R, Van der Ploeg LH, Weinberg DH. Analogs of MTII, Lactam Derivatives of Alpha-Melanotropin, Modified at the N-Terminus, and Their Selectivity at Human Melanocortin Receptors 3, 4, and 5. Biochem. Biophys. Res. Commun. 1999; 261(1):209213. [PubMed: 10405347]

10. Grieco P, Han G, Weinberg D, MacNeil T, Van der Ploeg LHT, Hruby VJ. Design and Synthesis of Highly Potent and Selective Melanotropin Analogues of SHU9119 Modified at Position 6. Biochem. Biophys. Res. Commun. 2002; 292(4):1075-1080. [PubMed: 11944925]

11. Haskell-Luevano C, Nikiforovich G, Sharma SD, Yang YK, Dickinson C, Hruby VJ, Gantz I. Biological and Conformational Examination of Stereochemical Modifications Using the Template Melanotropin Peptide, Ac-Nle-c[Asp-His-Phe-Arg-Trp-Ala-Lys]-NH2, on Human Melanocortin Receptors. J. Med. Chem. 1997; 40(11):1738-1748. [PubMed: 9171884]

12. Grieco P, Balse-Srinivasan P, Han G, Weinberg D, MacNeil T, Van Der Ploeg LH, Hruby VJ. Extensive Structure - Activity Studies of Lactam Derivatives of MT-II and SHU-9119: Their Activity and Selectivity at Human Melanocortin Receports 3, 4 and 5. J. Pept. Res. 2003; 62:199_ 206. [PubMed: 14531843]

13. Reimer U, Scherer G, Drewello M, Kruber S, Schutkowski M, Fischer G. Side-Chain Effects on Peptidyl-Prolyl Cis/trans Isomerisation. J. Mol. Biol. 1998; 279(2):449-460. [PubMed: 9642049]

14. Irani BG, Xiang Z, Yarandi HN, Holder JR, Moore MC, Bauzo RM, Proneth B, Shaw AM, Millard WJ, Chambers JB, Benoit SC, Clegg DJ, Haskell-Luevano C. Implication of the Melanocortin-3 Receptor in the Regulation of Food Intake. Eur. J. Pharmacol. 2011; 660(1):80-87. [PubMed: 21199647]

15. Greenfield JR, Miller JW, Keogh JM, Henning E, Satterwhite JH, Cameron GS, Astruc B, Mayer JP, Brage S, See TC, Lomas DJ, O'Rahilly S, Farooqi IS. Modulation of Blood Pressure by Central Melanocortinergic Pathways. N. Engl. J. Med. 2009; 360(1):44-52. [PubMed: 19092146]

16. Grieco P, Brancaccio D, Novellino E, Hruby VJ, Carotenuto A. Conformational Study on Cyclic Melanocortin Ligands and New Insight into Their Binding Mode at the MC4 Receptor. Eur. J. Med. Chem. 2011; 46(9):3721-3733. [PubMed: 21652123]

17. Wüthrich, K. NMR of Proteins and Nucleic Acids. New York: John Wiley \& Sons; 1986.

18. Marion D, Wüthrich K. Application of Phase Sensitive Two-Dimensional Correlated Spectroscopy (COSY) for Measurements of 1H-1H Spin-Spin Coupling Constants in Proteins. Biochem. Biophys. Res. Commun. 1983; 113(3):967-974. [PubMed: 6307308]

19. Braunschweiler L, Ernst RR. Coherence Transfer by Isotropic Mixing: Application to Proton Correlation Spectroscopy. J. Magn. Reson. 1983; 53(3):521-528.

20. Jeener J, Meier BH, Bachmann P, Ernst RR. Investigation of Exchange Processes by TwoDimensional NMR Spectroscopy. J. Chem. Phys. 1979; 71:4546-4553.

21. Wishart DS, Sykes BD, Richards FM. The Chemical Shift Index: A Fast and Simple Method for the Assignment of Protein Secondary Structure through NMR Spectroscopy. Biochemistry. 1992; 31(6):1647-1651. [PubMed: 1737021]

22. Roy A, Kucukural A, Zhang Y. I-TASSER: A Unified Platform for Automated Protein Structure and Function Prediction. Nat. Protoc. 2010; 5(4):725-738. [PubMed: 20360767]

23. Jaakola VP, Griffith MT, Hanson MA, Cherezov V, Chien EY, Lane JR, Ijzerman AP, Stevens RC. The 2.6 Å Crystal Structure of a Human A2A Adenosine Receptor Bound to an Antagonist. Science. 2008; 322(5905):1211-1217. [PubMed: 18832607]

24. Venkatakrishnan AJ, Deupi X, Lebon G, Tate CG, Schertler GF, Babu MM. Molecular Signatures of G-Protein-Coupled Receptors. Nature. 2013; 494(7436):185-194. [PubMed: 23407534]

25. Goodsell DS, Morris GM, Olson AJ. Automated Docking of Flexible Ligands: Applications of AutoDock. J. Mol. Recognit. 1996; 9(1):1-5. [PubMed: 8723313]

26. Rink H. Solid-Phase Synthesis of Protected Peptide Fragments Using a Trialkoxy-DiphenylMethylester Resin. Tetrahedron Lett. 1987; 28(33):3787-3790.

27. Thieriet N, Alsina J, Giralt E, Guibé F, Albericio F. Use of Alloc-Amino Acids in Solid-Phase Peptide Synthesis. Tandem Deprotection-Coupling Reactions Using Neutral Conditions. Tetrahedron Lett. 1997; 38(41):7275-7278. 
28. Grieco P, Gitu PM, Hruby VJ. Preparation of "Side-Chain-to-Side-Chain" Cyclic Peptides by Allyl and Alloc Strategy: Potential for Library Synthesis. J. Pept. Res. 2001; 57(3):250-256. [PubMed: 11298927]

29. Cai M, Cai C, Mayorov AV, Xiong C, Cabello CM, Soloshonok VA, Swift JR, Trivedi D, Hruby VJ. Biological and Conformational Study of Beta-Substituted Prolines in MT-II Template: Steric Effects Leading to Human MC5 Receptor Selectivity. J. Pept. Res. 2004; 63(2):116-131. [PubMed: 15009533]

30. Gantz I, Miwa H, Konda Y, Shimoto Y, Tashiro T, Watson SJ, DelValle J, Yamada T. Molecular Cloning, Expression, and Gene Localization of a Fourth Melanocortin Receptor. J. Biol. Chem. 1993; 268(20):15174-15179. [PubMed: 8392067]

31. Güntert P, Mumenthaler C, Wüthrich K. Torsion Angle Dynamics for NMR Structure Calculation with the New Program DYANA. J. Mol. Biol. 1997; 273(1):283-298. [PubMed: 9367762] 
a)

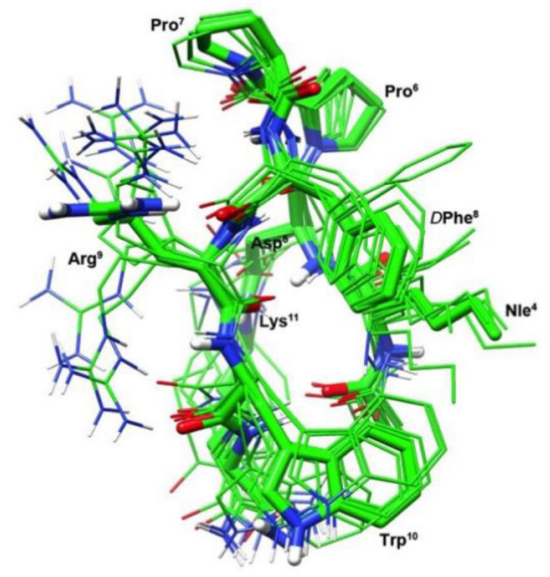

b)

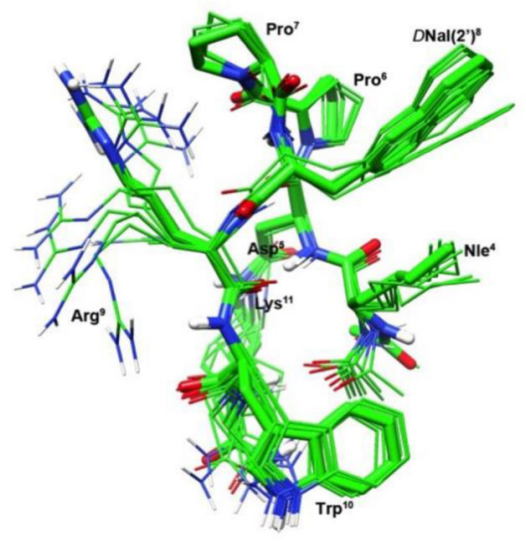

c)

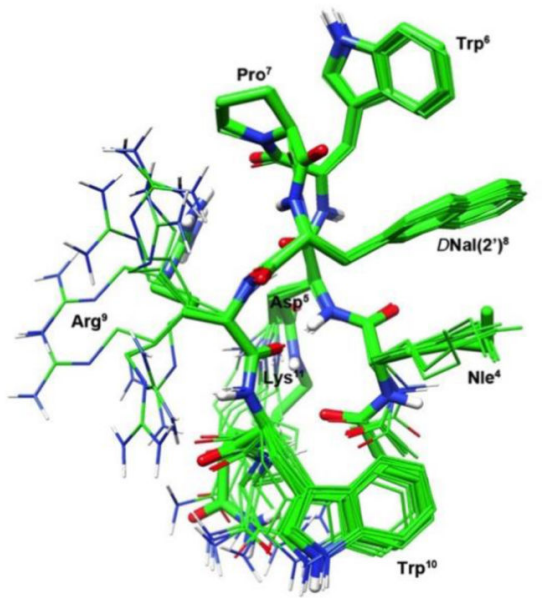

Figure 1.

Superposition of the 10 lowest energy conformers of peptide $\mathbf{1}$ (a), 2 (b), and $\mathbf{4}$ (c). Structure models were superimposed using the backbone heavy atoms. Heavy atoms have different colors (carbon, green; nitrogen, blue; oxygen, red; sulfur, yellow). Many hydrogen atoms are hidden for a better view. 

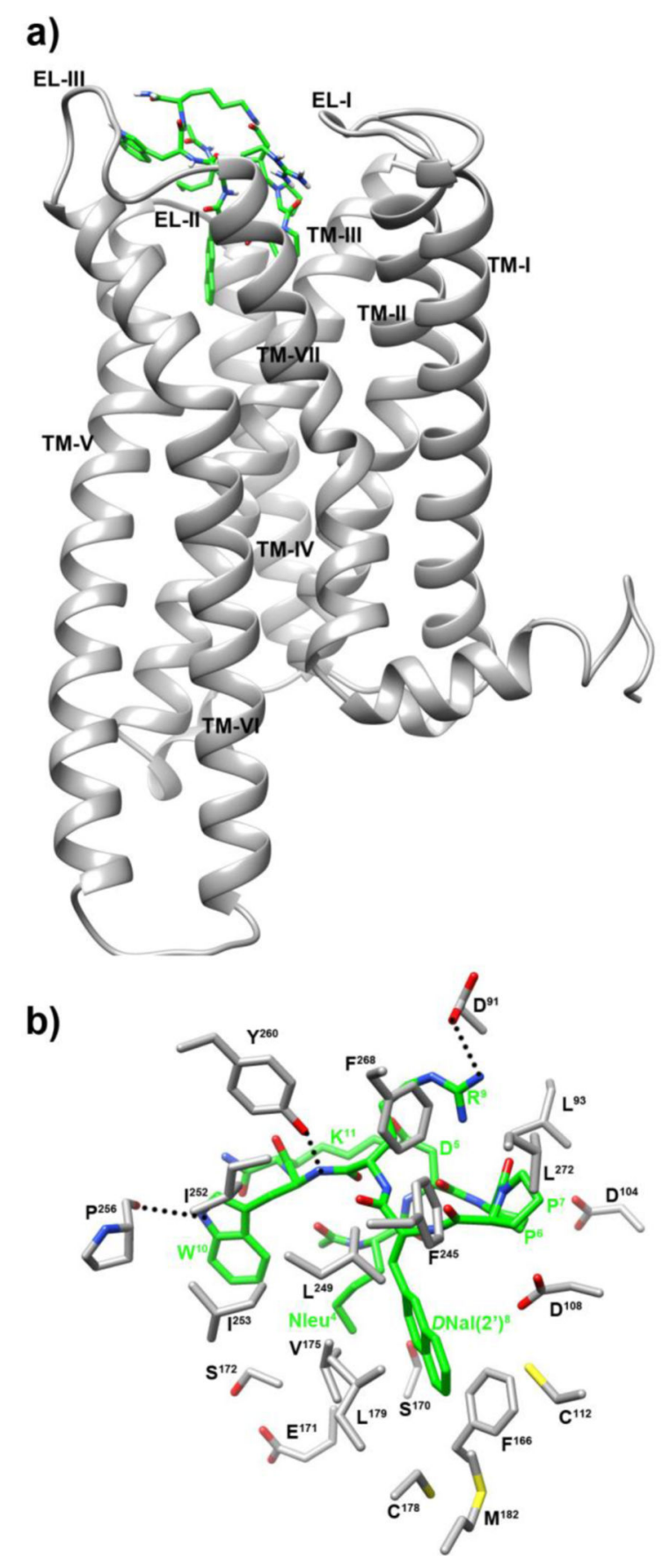

Figure 2.

(a) $h \mathrm{MC} 3 \mathrm{R}$ model complexed with peptide $\mathbf{2}$. Peptide $\mathbf{2}$ heavy atoms (carbon, green; nitrogen, blue; oxygen, red; sulfur, yellow). Receptor backbone is represented in gray ribbon. (b) Peptide 2 within the binding pocket of $h \mathrm{MC} 3 \mathrm{R}$. Hydrogen bonds are represented with dashed lines. 


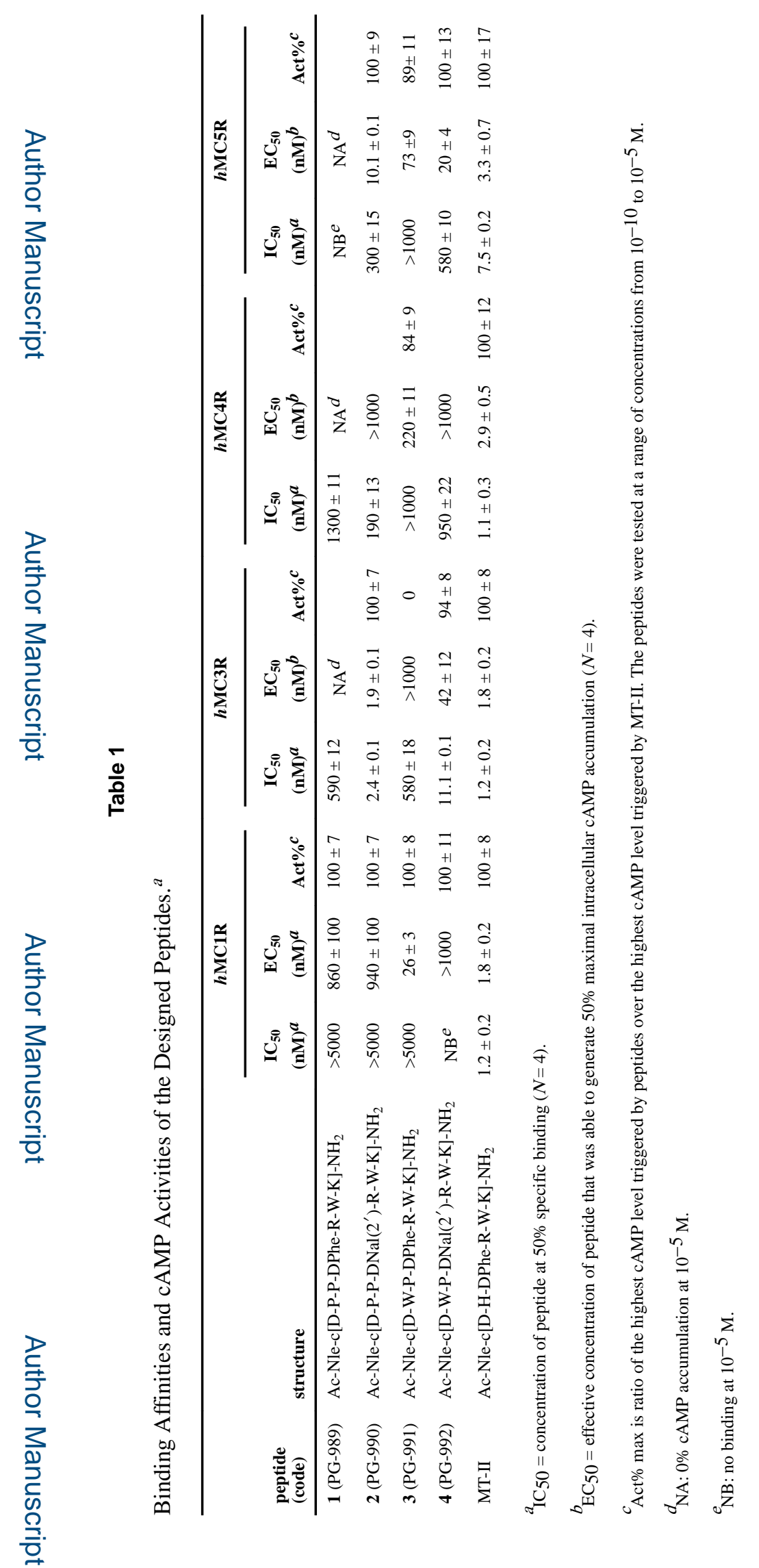

JMed Chem. Author manuscript; available in PMC 2016 October 19. 